\title{
A NAGYLÉPTÉKÚ FOTOVILLAMOS RENDSZEREK TÁMOGATÁSPOLITIKAI STRATÉGIÁINAK KÜLÖNBSÉGEI A KÁRPÁT-MEDENCE EGYES ORSZÁGAIBAN
}

\author{
VARJÚ VIKTOR \\ DIFFERENCES IN SUBSIDY POLICY STRATEGIES OF LARGE SCALE PHOTOVOLTAIC \\ SYSTEMS IN SOME COUNTRIES OF THE CARPATHIAN BASIN
}

\begin{abstract}
The EU2030 goal includes the increase of renewable energy share to at least of $27 \%$ of the EU's energy consumption. Renewables, especially photovoltaic energy investments and use, have become very popular in the last few years. New technologies and solutions can contribute to an increasing development in renewable energy. However, there are policy factors that can influence this process. In order to achieve renewable goals, governments began to support green electricity which caused a significant boom in installed capacity in some Carpathian Basin countries. However, on the one hand, this increase has caused negative effects, including the overuse of subsidies and the cut-back of supporting systems, as states could not maintain this high level of support. On the other hand, countries such as Croatia and Hungary maintained a slower increase of in-built photovoltaic capacity, thus keeping the state's subsidy amount (and the share of RES in energy consumption) low. Using the results of policy documents and development strategies, the author concludes by arguing that the key motivations behind investing in renewables differs state by state, and are influenced by central government. Based on the literature review and other researchers' findings, the funding of a balanced subsidy policy tool with three elements (Renewable Portfolio Standard, green certificate and feed-in tariff) can be a successful strategy.
\end{abstract}

Keywords: energy policy, renewable energy, subsidy, photovoltaics

\section{Bevezetés}

A megújuló energiák termelése, különös tekintettel a fotovillamos energiára, mára korábban soha nem látott méreteket öltött. Bár Európa és a világ energiafogyasztási struktúrájában szignifikáns elmozdulás a 21. század elején még nem történt meg (RUDLNÉ BANK K. 2008), a mégis egyre inkább érzékelhető változásban alapvető szerepet játszik a környezet- és energiatudatos közgondolkodás mellett (vö. pl. NÉMETH K. 2017, CsOMÓs GY. 2014) a támogatáspolitika, amely szintén rendszerszemléletû megközelítést igényel (NÉmeth K.-PÉTER E. 2017). A rendszerek telepítése 2005-től nőtt meg számottevően, különösen az Európai Unióban, ahol Németország 2004 óta tartja piacvezető helyzetét (JÄGER-WALDAU, A. 2017). Az EU 2017-ben először több villamos energiát termelt megújuló forrásból (egészen pontosan szél-, nap- és biomassza-energiából), mint szénből. A (Dánia mellett) éllovas Németországban 2017-ben a villamos energia 30\%-át termelték meg szél-, nap-, illetve biomassza-erómúvek segítségével. Ez az arány a jelen tanulmányban vizsgált országok esetében az alábbi: Románia 16\%, Horvátország 18\%, Szlovákia 8\%, míg Magyarország 10\% (https://www.photon.info/en/news/2017-europe-more-electricity-was-generated-renewable-sources-coal).

Bár a megújuló energia termelésében a földrajzi körülményeknek meghatározó a szerepe, a fotovillamos energia esetében ez egyre kevésbé igaz, illetve a szabályozási változások a számokat is módosíthatják (1. pl. a tűzifahasználat statisztikai módszertanának változását: COM [2015] 328). A technológiák átvételének köszönhetően a használat egyre 
szélesebb körű. A megújuló energia további térnyerését elsősorban a fejlesztéspolitikai, környezetpolitikai szándék, illetve a támogatáspolitika befolyásolja.

Bár az Európai Unió megújuló energetikai céljai 2020-ig stabilnak tekinthetők - mindamellett, hogy COM (2014) 15 Bizottsági Közleményében a megújuló energia részarányát 2030-ra legalább 27\%-osra kívánja emelni -, a nemzeti stratégiák folyamatosan változnak. Ez elsősorban a támogatáspolitikákban mutatkozik meg. Ebben a tekintetben a hazai támogatáspolitika különösen változékony, beleértve a napelemekre kivetett környezetvédelmi adó bevezetését, vagy a jelen cikk írásakor felfüggesztett (92/2018. (IV. 27.) Korm. rendelet) METÁR/KÁT támogatási rendszert. A változékonyság tetten érhető számos Kárpát-medencei országban is, ott jellemzően egyfajta beruházási boomot követően. A különböző országok más és más támogatáspolitikai stratégiát választottak a megújuló energiaforrások előretörésekor, azonban a rendelkezésre álló támogatási források csökkenése miatt a stratégiák különbözőképpen változnak. A támogatáspolitikai stratégiák változásának röppályáit próbálja felvázolni jelen cikk a Kárpát-medence - FODOR IsTVÁN professzor úr kedvelt kutatási területe - néhány országában.

\section{Jellemző támogatáspolitikák a megújuló-energetikai iparban}

A megújuló energiaforrásból termelt villamos energia valamilyen formájú támogatása világszerte bevett dolog. A támogatáspolitika egyik fő célja a fosszilis tüzelőanyagok elégetéséból származó nem beárazott szennyezés (externális költségek) korrekciója (Borenstein, S. 2012). Jenner, S. et al. (2013) szerint a támogatásokban két fő megközelítés különböztethetô meg: a politika vagy a megújuló energiaforrásból származó villamos energia árát, vagy a termelt mennyiséget szabályozza. Mindezek mellett maga a beruházás is gyakorta támogatást élvez (JENNER, S. et al. 2013). Ugyanakkor NAGY S. GY.-LóRÁND B. (2013) arra is rámutatnak, hogy a vissza nem térítendő támogatások nem motiválják a szereplőket versenyképességük növelésében.

A fix vagy garantált átvételi ár (vagy betáplálási tarifa; feed-in-tariff) a legelterjedtebb ösztönzési módszer, időnként prémiumárral és zöldbizonyítvánnyal kombináltan (MEZEI C. 2014), és a szakirodalom szerint (NiCOLINI, M.-TAVONI, M. 2017) bizonyítottan ez a leghatékonyabb eszköz is, amely elősegíti a megújuló energiák leggyorsabb fejlődését, tekintetbe véve annak pontos gazdasági, megtérülési, fejlesztésösztönzési hatásait. A betáplálási tarifa lényege, hogy a megújuló energiaforrásból termelt elektromos áram átvételi árát fix módon garantálja; ez az ár pedig magasabb, mint a szokványos piaci ár, ösztönözve ezzel a technológia telepítését (PRŮŠA, J. et al. 2013, NiCOLINI, M. - TAVONI, M. 2017). Ezen támogatásforma hatása azonban függ az országok sajátosságaitól, a kialakított szakpolitika egyedi kereteitől (MendonçA, M. - JACoBs D. 2009, Couture, T. - Gagnon, Y. 2010, Timilsina, G. R. et al. 2012, Jenner, S. et al. 2013, SARASA-Maestro, C. J. et al. 2013). A garantált átvételi árat sok tekintetben szabályozzák. A legtöbb országban bizonyos beépített kapacitás felett már nem biztosítják a kedvezményes feltételeket, illetve bizonyos időtartamhoz kötik, amely alatt a magasabb tarifa jár a megújuló villamos energiáért. Ugyanakkor, ahogy arra több tanulmány (pl. SARASA-MAESTRO, C. J. et al. 2013) is rámutat, sok helyen a magasan meghatározott átvételi árak átgyúrúznek a lakossági árakba, illetve (olykor spekulatív) befektetői csoportok erőteljes megjelenését eredményezik a fotovillamos szektorban, meghatározó szerephez juttatva ooket, háttérbe szorítva az önkormányzati vagy közösségi kezdeményezéseket. (Ausztráliában - ellenpéldaként az üvegházhatású gázok kibocsátása összes csökkentésének feléért az önkormányzatok a „felelősek” - CheunG, G. et al. 2016.) 
A fotovillamos beruházások egyre kisebb gazdasági kockázata, valamint a magánszektor térnyerése miatt számos ország olyan ösztönzési rendszer irányába mozdul el (pl. prémiumrendszer, tendereztetés), amely továbbra is fenntartja a megújuló energia használatának támogatását, azonban ahhoz mind kisebb közösségi pénzből való hozzájárulást ad, és esetlegesen területileg is differenciálja a támogatásokat. Így Németországban is megindult a fotovillamos energia támogatásának csökkentése, ahol a kapacitás, valamint a telepítés éve alapján csökkenő átvételi árakat biztosítanak a termelőknek. A 2010-es nagyobb mértékú tarifacsökkentést követően a támogatási ár 9\%-kal csökkent 2011 és 2014 között (SARASA-MAESTRO, C. J. et al. 2013). Hiába azonban a magas kötelező átvételi ár, amely megfelelő megtérülési időt biztosít a beruházónak, ez a támogatás nem segíti a magas induló (beruházási) költségekhez való hozzájárulást (COUTURE, T.-CORY, K. 2009), ugyanis nagy induló tőke szükséges még a különböző beruházás-támogatási eszközök jelenléte esetén is. A kötelező átvételi tarifával kapcsolatban TimiLsinA, G. R. et al. (2012) felhívják a figyelmet még egy sajátos területi szempontra is: a tapasztalatok szerint a hálózatba kapcsolt rendszereknél az átvételi árak nem számolnak az erômú területi elhelyezkedésével, ami nagy távolságok esetén megnöveli a betáplálási és szállítási költségeket is.

A prémium, amelyhez gyakran tendereztetési eljárás is társul, a ,zöldenergia”-termelés nagysága alapján kalkulált, a (piaci) átvételi árra rakódó kiegészítő összeg, amellyel a megújuló energiaforrásból termelt áramot ,,jutalmazzák”. Jellemző, hogy a piaci átvételi ár és a prémiumár együttesen rendszerint kisebb, mint a garantált átvételi ár értéke. Kizárólag prémiumon alapuló ösztönzési rendszert Ciprus és Dánia múködtet (JENNER, S. et al. 2013).

A kvótarendszer jellemzője, hogy a megújuló energiaforrásból termelt villamos energia - vagy egyéb, pl. hőenergia - egy bizonyos (szerződött) mennyiségére, kvótájára az állam, illetve az állam egyetemes szolgáltatója, elosztója garantált átvételt biztosít. A kvóta nagysága jellemzően függ a megújuló energiaforrás típusától, valamint a termeló erőmú kapacitásának nagyságától, továbbá mennyisége évenként is eltérhet. A kvótákra rögzített időszakokra fix átvételi ár is megadható. Ugyanakkor „A zöldbizonyítvány-rendszer az ellátási lánc valamely elemére (például fogyasztás, elosztás) kivetett kötelezettségen alapul, amelynek értelmében a teljes villamosenergia-felhasználás bizonyos hányadának megújuló erőforrásokon nyugvó termelésből kell származnia. A kötelezettség teljesítésének igazolásához szükséges a zöldbizonyítvány” (HVG 2011). „Ezeknek a zöldbizonyítványoknak aztán kialakul egy másodlagos kereskedelmi rendszere is (mint ahogy a $\mathrm{CO}_{2}$ kvótáknak is), ami drágíthatja a rendszer múködtetését” (MEZEI C. 2014, p. 39.).

A fenti két rendszer egy hibrid megoldása a „zöldbizonyítvány kvótarendszerrel”. A kvótarendszer általában úgy ismert, mint kvótakötelezettség, amit az Egyesült Államokban „megújuló portfólió sztenderdnek” (Renewable Portfolio Standard, RPS) hívnak. Az energia árát a programban résztvevő szereplők alakítják ki, valamint a kvótákkal kereskedni is lehet (Timilsina, G. R. et al. 2012, SARAsA-Maestro, C. J. et al. 2013). A rendszer lényege, hogy a megújuló erőforrásból energiát termelő szereplő az alkalmazott technológiától függően különböző mennyiségű zöldbizonyítványt kap. A villamosenergia-elosztó cégnek áramkvótát kell vásárolnia a zöldbizonyítványok segítségével, meghatározott minimum és maximum ár között. Az elosztó cégnek további kötelezettsége, hogy zöldbizonyítványt vásároljon a megújuló termelőktől, amelynek költségeit majd az áram eladási árában érvényesítheti (CĂMPEANU, V.-PENCEA, S. 2014). A tendereztetési eljárásban aukciók során, vagy más pályázati eljárásban osztanak ki kvótákat, (esetleg prémiumokat), amelyek alapján a kedvezményezettek különböző előnyökre (pl. támogatott átvételi ár) jogosultak (SARASA-MAeStro, C. J. et al. 2013). Az ilyen eljárás segít differenciálni, így akár a területi egyenlőtlenségeket is figyelembe lehet venni a kedvezmények kiosztásánál. 
Mivel a naperőmúvek magas múködési támogatása ellenére az induló tőkeigény még így is magas, az invesztíció különböző támogatásformái is megjelennek szerte a világon. A beruházási ÁFA elengedése (pl. Brazíliában, 1. http://photon.info), vagy más adótámogatás (pl. kedvezmény az iparúzési adó vagy a nyereségadó terén) is a beruházások ösztönzését hivatott szolgálni. Az Egyesült Államokban például ún. beruházásiadó-kreditet biztosítanak a napenergetikai és üzemanyagcellás beruházásokhoz (TIMILSINA, G. R. et al. 2013). A beruházás közvetlen támogatása mellett kedvezményes hitelekkel is segítik a naperőmúvek telepítését.

A fotovillamos energiatermelés elterjedését nem csak a magántőke ösztönzésével segítik. A közösségi pénzekből megvalósuló beruházások az elmaradott téregységeknek biztosítanak felzárkózási lehetőséget azzal, hogy akár hálózatba kötött, de fóként decentralizált rendszerekkel biztosítanak elektromos áramhoz való hozzáférhetőséget. Ilyenre találhatunk példát Kínában is. Itt, ahogy TimiLsinA, G. R. et al. (2012) rámutatnak, a fotovillamos ipar és piac gyors fejlődésében az állam nagymértékben szerepet játszott, hiszen számos vidéki villamosítási programot támogattak az 1990-es évek végén, a 2000-es évek elején. Az állami források mellett nemzetközi segélyeket is bevontak. Ilyen bilaterális vagy multilaterális vidéki energiafejlesztési projektet indított például a Világbank is, a Fülöp-szigeteken, ahol a cél 135000 napelemes rendszer kiépítése volt (TIMILSINA, G. R. et al. 2012).

\section{Fotovillamos és megújuló energetikai potenciálok}

Az egyes megújuló energiaforrások rendelkezésre álló potenciálját számos kutatás vizsgálja. A ,legegyszerűbb” módszer a napenergia-potenciál becslésére az (EU finanszírozású) PVGIS (http://re.jrc.ec.europa.eu/pvgis/) használata, ahol a térinformatikai adatbázis tartalmazza a besugárzási adatokat évszakos bontásban is, sôt, az elektromos áram előállítási költségeire vonatkozó (LCOE) számításokat is bizonyos napelemtípusokat illetően, standard tesztkörülményeket figyelembe véve. A gyártók által megadott paraméterek azonban csak hozzávetőlegesek, nem a valóságot tükrözik, így a potenciálszámításoknál már számos más tényezőt is figyelembe kell venni, és célszerű adott térségre vonatkozó méréseket is végezni (vö. PELIN, D. et al. 2014).

ŠLJIVAC, D. (2015) az ECOFYS 2005 alapján 5 típusú potenciált különböztet meg, amelyet a potenciálbecslésnél célszerű figyelembe venni:

- elmélet potenciál: a legnagyobb potenciál, amely az éghajlati, illetve általában a természeti tényezőket figyelembe véve lehetséges;

- földrajzi potenciál: az erőforrás elméleti potenciáljának földrajzi helyzetből adódó korlátozása, tekintettel arra, hogy a legtöbb megújuló energiaforrásnak van földrajzi korlátja, mint például a földhasználat vagy a felszínborítottság;

- technikai potenciál: a megújuló energiát milyen hatékonysággal alakítja át a technológia elektromos árammá vagy pl. hőenergiává, ugyanis a földrajzi potenciált tovább korlátozza a technika, a technológia, amely elsősorban az átalakítási hatékonyság formájában jelenik meg;

- gazdasági potenciál: a költségszintek figyelembe vétele, tekintettel a versenyképességre is;

- és végül a piaci potenciál: a megújuló energiaforrásnak az a mennyisége, amely bevezethetô a piacra, figyelembe véve az energiaigényt, a versenyző technológiákat, a megújuló energia költségét és támogatását, valamint a különböző egyéb akadályokat. 
A szakirodalomban a potenciálbecsléseknél kétféle trend figyelhető meg. Egyrészt a fenti potenciálkategóriákon túlmenően a felhasználható valódi potenciállehetőségeket további keretfeltételek mentén finomítják. Így pl. FARKAS I. $(2005,2010)$ már részletesen taglalja a napenergia hasznosítási lehetőségeit, részletesen bemutatva a mezőgazdasági hasznosítást, s potenciálbecslést adva az egyes hasznosítási lehetőségekre a szektorban; VÉGH L. (2015) a területhasználat mellett az elektromos fővezetékek eloszlását is figyelembe veszi; míg KASSAI-SzOó D. (2014) a városi terek tetőpotenciálját modellezi, tekintettel a dőlésszögre, árnyékolásra és más korlátozó tényezőkre. A másik típus, amikor egy nagyobb téregység vagy ország megújuló potenciálját komplex módon kívánják megfogni, figyelembe véve egyszerre több megújuló energiaforrás-típust. Ilyen pl. PÁLFY M. (2017) Magyarországra vonatkozó munkája, amely nyolc épülettípust, két hasznosításra alkalmas területhasználati formát és két vonalas infrastruktúrát megkülönböztetve számításokat publikál, figyelembe véve mindegyik típusnál négyféle lehetséges dőlésszöget. Az előrehaladottabb vizsgálatok a komplex potenciál-indikátor kialakításakor az igények mellett jellemzően figyelembe veszik és integrálják a lokális társadalmi-gazdasági keretfeltételeket is (pl. KATSAPRAKAKIS, D. A. -Christakis, D. G. 2016; BenedeK J. et al. 2018).

Magyarországon a Magyar Tudományos Akadémia Megújuló Energetikai Albizottsága a Magyar Napenergia Társasággal (MNT) együttmúködve 2004-ben felmérést készített a magyarországi napenergia-potenciálról (FARKAS I. 2010). A szakértői csapat a közvetlen hasznosításra vonatkozóan négy fó kategóriát különböztetett meg: 1. aktív szoláris termikus rendszerek; 2. a mezőgazdaság szoláris termikus alkalmazásai; 3. energetikai célú szoláris fotovillamos-hasznosítás; 4. passzív szoláris termikus rendszerek (FARKAS I. 2017). A térinformatikai és távérzékelési módszerek mellett terepi felmérések is segítik a potenciál-becslést, kataszterek kialakítását a megújuló energiaforrások minél jobb felhasználása érdekében (pl. Tóтн A. N. 2016).

A fent bemutatott kísérletek fontosak abból a szempontból, hogy körüljárják azokat a megengedő feltételeket és akadályozó tényezőket, amelyek az elméleti potenciált korlátozzák. Ezeknek a munkáknak az összegzése önmagában is külön tanulmányt kívánna, ezért velük részletesen e helyütt a szerző nem foglalkozik. Ennek az is oka, hogy a rendelkezésre álló potenciálok kihasználásának közelében jellemzően még nem járunk, másrészt a megújuló forrásokból történő energiatermelés jelenlegi, ,serdülőkorúnak” nevezhető szakaszában a rendelkezésre álló potenciált, mint korlátozó tényezőt jellemzően megelőzi a támogatáspolitika, mint a megújuló energiaforrások használatát ösztönző, illetve korlátozó tényező (1. pl. MuNKÁCSY B. [2010] szélenergia-potenciállal kapcsolatos fejtegetéseit).

\section{A fotovillamos energia támogatáspolitikai háttere néhány Kárpát-medencei országban}

Ha megvizsgáljuk a PVGIS besugárzási térképét (1.ábra), akkor az látható, hogy a vizsgált 4 Kárpát-medencei ország napenergia-potenciálja nem teljesen egyenlő. A legroszszabb helyzetben Szlovákia van, míg Románia és Horvátország déli területei kifejezetten magas értékeket mutatnak. Mindemellett Magyarország helyzete relatíve jó, különösen a déli országrészé.

Ha azonban megnézzük azt, hogy az elmúlt 10 évben hogyan alakultak (2. ábra) a fotovillamos energetikai beruházások a vizsgált országokban, azt láthatjuk, hogy azok a földrajzi potenciállal nem korrelálnak. Ennek alapvető oka a támogatáspolitikában keresendő. 


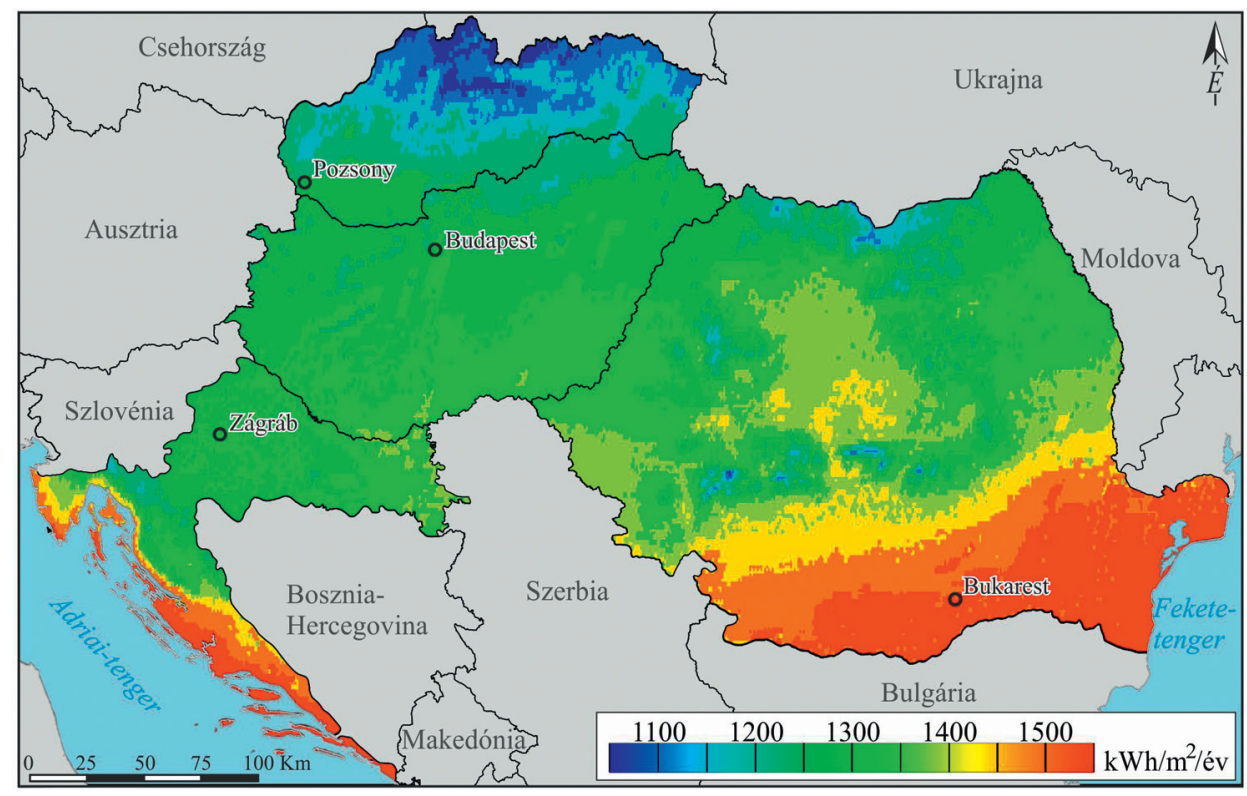

1. ábra Éves átlagos globális besugárzás vízszintes felületen a vizsgált Kárpát-medencei országokban $\left(\mathrm{kWh} / \mathrm{m}^{2}\right)$ (2007-2016 átlaga). PV GIS adatok alapján szerk. VARJú V., rajzolta Szabó T.

Figure 1 Annual global solar radiation on horizontal surface in the analysed case study countries $\left(\mathrm{kWh} / \mathrm{m}^{2}\right)$ (Average of 2007-2016). Based on PVGIS data ed. by VARJú, V., designed by Szabó, T.

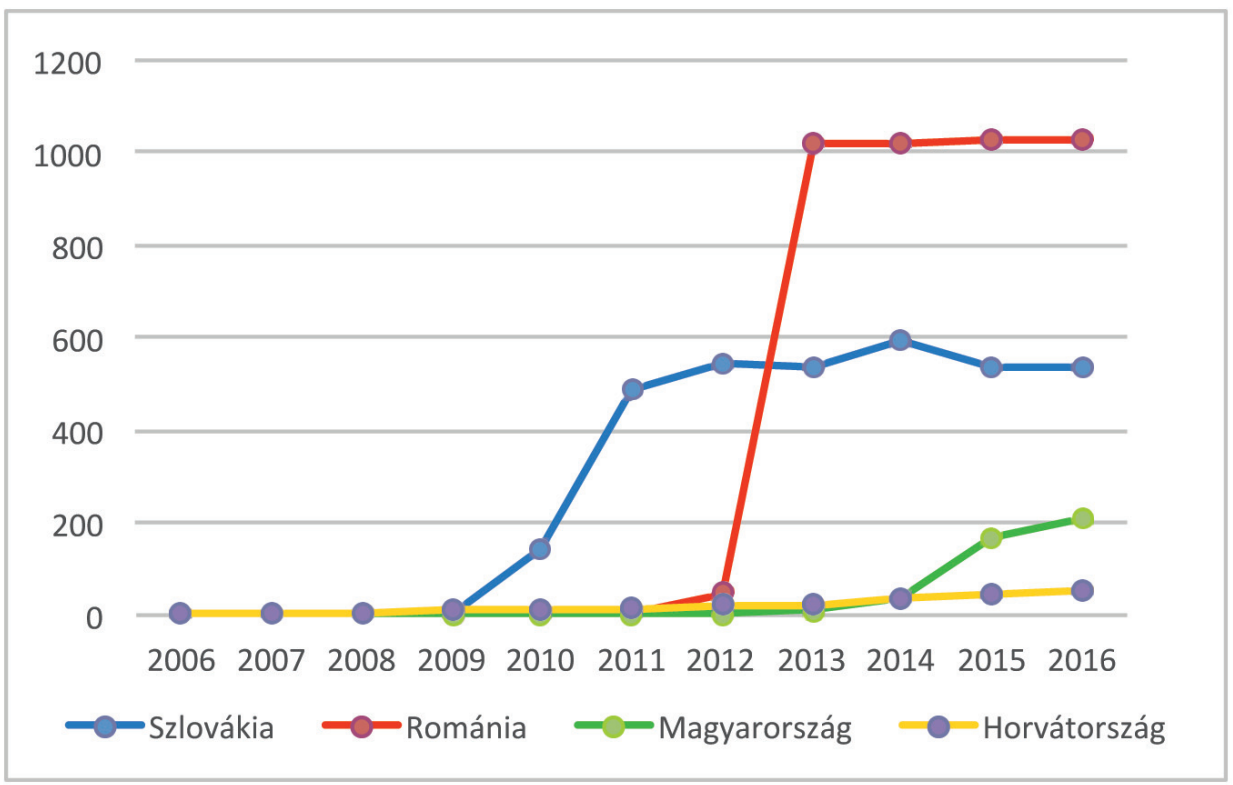

2. ábra Összesített telepített fotovillamos-kapacitás néhány Kárpát-medencei országban, 2006 és 2016 között (MW).

Dusonchet, L.-TelaretTi, E. (2010); EurObserv'ER, valamint http://photon.info adatok alapján szerk. VARJÚ V.

Figure 2 Cumulative photovoltaic in-built capacity in some countries of the Charpatian Basin between 2006 and 2016 (MW).

Ed. by VarJú, V. based on Dusonchet, L.-TelaretTi, E. (2010); EurObserv'ER, and http://photon.info 
A megújuló energiaforrásból termelt villamos energia támogatási rendszereinek kialakítását a nyugati tagországok már az 1990-es években megkezdték, míg a kelet-közép-európai országokban ez a folyamat csak a 2000-es években indult el, jobbára a már említett megújuló energetikai irányelv hatására. Az itt tárgyalt országok vállalásai különbözők, sokuk mára egy robbanásszerű fejlődés következményeként megközelítette (vagy meghaladta) a 2020-as célértékeket (1. táblázat); a fejlődést azonban egy korlátozó időszak követte.

A vizsgált Kárpát-medencei országok EU2020-as vállalásai

1. táblázat-Table 1 a bruttó energiafogyasztáson belül a megújuló energia részarányát illetően és az arányok 2016-os állása. Forrás: Eurostat

The EU2020 goals of the analysed countries of the Carpathian Basin regarding the rate of the renewable energies

in the total energy consumption and their rate in 2016. Source: Eurostat

\begin{tabular}{lcc}
\hline & 2020-as célérték $\mathbf{( \% )}$ & 2016-ig elért érték $\mathbf{~}^{\mathbf{1}} \mathbf{( \% )}$ \\
\hline Magyarország & 13,00 & 14,20 \\
Szlovákia & 214,65 & \\
Horvátország & 14,00 & 12,00 \\
Románia & 20,00 & 28,30 \\
\hline
\end{tabular}

${ }^{1}$ A COM (2015) 328 módszertani változásai után

${ }^{2}$ A megújulóenergia-hasznosítási cselekvési tervben szereplő ambiciózusabb részarány

JENNER, S. et al. (2013) gyűjtése alapján a vizsgált térben 2003-ban először Szlovákia vezetett be meghirdetett adótámogatási, illetve beruházás-támogatási ösztönzőt a megújuló energiaforrásból származó villamosenergia-termelés előmozdítása érdekében. 2002-ben Magyarország és 2005-ben Szlovákia indított fix, vagy prémium átvételi ártámogatási rendszert, többek között a fotovillamos áram átvételére. Románia 2008-ban a kvótarendszer mellett tette le voksát (JENNER, S. et al. 2013). Ahogyan a későbbiekben láthatóvá válik, az időtényező nincs hatással a fotovillamos (és általában a megújuló) energia termelésének fejlődésére.

\section{Szlovákia}

A szlovákiai fotovillamosenergia-termelés fejlődésére a megkésettség és a robbanásszerű növekedés a jellemző. 2006-ig a beépített kapacitás $20 \mathrm{~kW}$ volt, és 2008 -ig is csak $66 \mathrm{~kW}$-ig emelkedett, majd a dinamikus növekedés 2010-től figyelhető meg (DusONCHET, L.-TelaretTi, E. 2010, HoreCZKi R. 2014) (2.ábra). Az EU 2020 célok eléréséhez 2009ben a szlovák kormány az energiaelosztó vállalattal kötelezettséget vállalt, hogy a fotovillamos rendszerekben termelt villamos energiát 15 éven keresztül átveszi. A 2009 szeptemberében kialakított betáplálási prémium az egyes energiatermelő típusokhoz, a telepítés időpontjához és technológiájához, valamint a mérethez igazodva állapítja meg az átvételi prémiumokat, figyelembe véve a veszteségek elkerülését. Az alapár, amelyre a prémium rakódik, 15 évig biztosított a megújuló forrásból termelők részére. A 2007-2013-as uniós tervezési időszakban a Szlovák Innovációs és Energia Ügynökség Versenyképességi és Gazdasági Növekedési Operatív Programjában a strukturális alapok felhasználásával a konvergenciarégiók részére pályázati lehetőségeket biztosított kis- és középvállalkozások részére megújuló energetikai beruházásra (DusonCHET, L.-TELARETTI, E. 2010). Az át- 
vételi ár kezdetben nagyon nagyvonalú volt, így 2010-re a fotovillamos beépített kapacitások Szlovákiában elérték az 500 MW-ot. Ennek következtében 2010-ben az átvételi árakat mintegy 33\%-kal csökkentették, majd 2012-ben újabb vágás következett, így az a 2009-es ár kevesebb mint felére apadt (CSIKÓsová, A. et al. 2012).

\section{Románia}

2012-ben a megújuló energetika befektetési térképén Románia „paradicsomként” szerepel az Ernst \& Young (2012) elemzésében. A megújuló energiaforrások használata robbanásszerűen növekedett meg. Amíg 2009-ben a megújuló forrásból származó energia termelésére alkalmas kapacitás 12 MW volt, a 2010-től felgyorsuló növekedés következtében ez az arány 2013-ra 2880 MW-ra növekedett; ebból a fotovillamos energia növekedése $1100 \mathrm{MW}$ volt, 2013 végére elérve az $1150 \mathrm{MW}$ beépített kapacitást (http://www. photon.info/photon_news_detail_en.photon?id=85019). A növekedés okait CăMPEANU, V.-PENCEA, S. (2014) négy fő tényezőcsoportba sorolják:

- a kedvezó globális és európai háttér;

- az európai és romániai ösztönző jogi keretek;

- Románia természeti potenciálja (egy, az összes megújuló erőforrást figyelembe vevő index - All Renewables Index-ARI - alapján Románia a világon a 13. helyen áll, 1. TAPURICA, O. C.-TACHE, F. 2014);

- a megújuló energetika fejlesztését ösztönző európai és romániai környezetpolitika.

Dusonchet, L. - TELARETTI, E. (2010) még azt is kiemeli, hogy a naperőmúvek prioritást élveznek a hálózathoz csatlakozáskor, valamint a csatlakozási folyamat egyszerúsített.

CĂMPEANU, V.-PENCEA, S. (2014) a megújuló természeti potenciállal kapcsolatban az alábbi feltételeket említi:

- hatalmas területek állnak rendelkezésre szél- és naperômúvek építésére, ami csökkenti a költségeket, különösen az olcsó földvásárlás okán (érdemes azonban megjegyezni, hogy ezt a potenciált kellő fenntartással szabad csak kezelni, mivel a hivatkozott szerzők nem írják, hogy itt pontosan milyen területekre gondolnak, pl. barnamezős területekre, olcsó szántóterületekre, vagy kivett mezőgazdasági területekre, és azt sem, hogy vizuális szennyezéssel kell-e számolni, és ha igen, milyen mértékben);

- az ország a legnagyobb szélpotenciállal rendelkezik Délkelet-Európában, míg a második legnagyobbal a kontinensen;

- korlátlannak tűnik a lehetőség offshore szélerőmúvek telepítésére a Fekete-tengeren (a potenciál felmérésére folyamatos kísérlet zajlik, 1. pl. AyDOĞAN, B. 2017);

- relatíve fontos a napenergia-potenciál;

- és a biomassza a legnagyobb elérhetó megújuló energiaforrás Romániában.

Ezekre az eróforrásokra alapozva Románia azt tervezi, hogy energiaigényének 73\%-át megújuló eróforrásból fogja fedezni 2050-re (CĂMPEANU, V. - PENCEA, S. 2014).

Romániában - Belgium, Dánia, Észtország, Lengyelország és Svédország mellett nem használják a betáplálási tarifa rendszerét, itt a zöldbizonyítvány politikája múködik (CĂMPEANU, V.-PENCEA, S. 2014). A zöldbizonyítvánnyal kombinált kvótarendszer SARASA-MAESTRO, C. J. et al. (2013) szerint az állampolgárok által azért elfogadott, mert nem abszorbeálja a költségeket az áramtarifába (bár ennek CĂMPEANU, V. - PENCEA, S. (2014) ellentmondanak, rámutatva arra is, hogy a fogyasztói ár növekedése miatt Románia más támogatási megfontolás irányába mozdul el). Ahogyan HoRECzKi R. (2014) is jelzi, „a fejlődés egyik oka, hogy a befektetőknek nincs problémája az értékesítéssel, hiszen az így elóállított energia költsége negyede az eladási árnak, valamint az állam jelentős támogatásokkal segíti elő a zöldenergia termelését” (p. 108). 
A Romániában múködő zöldbizonyítvány-rendszer azért tud fejlődést kelteni a megújuló energia termelésében, mert az egyes eróforrástípusokhoz nagy mennyiségú, a befektetôk számára vonzó zöldbizonyítványt rendel (pl. 2 bizonyítvány a szélerőmúvek, 6 bizonyítvány a naperőmúvek, 2-3 bizonyítvány a biomassza, biogáz által villamos energia termelésére alkalmas erómúvek megawattonkénti beépített kapacitására vonatkozóan), és ezek meghatározott maximalizált kereskedelmi ára is magas (56,44 EUR 2012-ben, 58,823 EUR 2013-ban zöldbizonyítványonként). A befektetésösztönzés olyannyira koncentrált, hogy a 2012-ben Romániába irányuló külföldi tőkebefektetések (FDI) egyharmada a szélerômúiparba irányult (CĂMPEANU, V.-PENCEA, S. 2014)!

A kedvező támogatáspolitikának megfelelően csak 2012-ben 23 MW új fotovillamoskapacitás épült ki az országban, 2013-ban pedig a kapacitás 121\%-kal emelkedett, így 2013 szeptemberére ez a kapacitás elérte a 600 MW-ot, 2016 végére pedig meghaladta az 1000 MW-ot (2.ábra). Mindezeknek köszönhetően Románia már elérte a 2020-ra vállalt uniós megújuló részarányt (CĂMPEANU, V.-PENCEA, S. 2014) (1. táblázat).

A növekedés hatásai azonban a fogyasztói energiaárak növekedésében is tetten érhető, mind az ipari, mind a lakossági fogyasztók vonatkozásában. Az energiaintenzív iparágak az elmúlt 1-2 évben a fenti tényezők miatt versenyhátrányba kerültek. A fogyasztói árak csökkentése érdekében a kormány elhatározta, hogy csökkenti a zöldenergia támogatását, mind a már meglévo, mind pedig az újonnan telepítendő megújuló erőforrást használó erőmúvek esetében. A megawattonként kiadott zöldbizonyítványok száma 2017 márciusától 2 bizonyítványra csökken a naperőmúvek esetében (míg 1-re a szél- és vízerőmúveknél). További szigorítás, hogy azok a naperőmúvek, amelyek mezógazdasági hasznosítású területre épülnek, 2013 júliusától nem részesülhetnek a zöldbizonyítvány előnyeiből, valamint az 5 MW feletti fotovillamos erőmúvek sem kapnak zöldbizonyítványt. A zöldbizonyítványért adható maximálisan elfogadott piaci ár is lecsökkent $30 \mathrm{EUR} / \mathrm{MW}$-ra (míg a minimum ár megmaradt 27 EUR/MW-on) (CĂMPEANU, V. - PENCEA, S. 2014).

Bár Románia a támogatások csökkentése miatt a befektetôk elmaradásától tart, CĂmPEAnU, V.-PEnCEA, S. (2014) azt javasolják, hogy érdemes figyelembe venni 2017 után egy teljes átállást a betáplálási tarifa rendszerére, mivel olcsóbb, és könnyebb a végrehajtása is. Mindemellett TAPURICA, O.-C.-TACHE, F. (2014) felhívják a figyelmet arra, hogy Romániában sem az energiahatékonyság kérdése, sem pedig a megújuló energiaforrások promóciójának menedzselése nem volt hatékony, a fejlődés az EU finanszírozásnak köszönhető. A közösségi (strukturális) alapok támogatásintenzitása átlagosan 41,94\% volt a fenntartható energiafejlesztések esetében, így a befektetőknek a beruházási érték csak mintegy 58\%-át kellett biztosítani. A fenntartható energia 1030 millió eurós fejlesztési költségvetésének több mint 28\%-át energiahatékonyságra, míg közel 72\%-át megújuló energetikai fejlesztésekre fordították 2007 és 2013 áprilisa között. A források majd 40\%-a a szél-, míg mintegy egyharmada vízerőmú-kapacitások fejlesztésére lett felhasználva, amelynek oka az volt, hogy a befektetők az alacsonyabb kockázatot és a nagyobb tapasztalatot keresték. Ezzel szemben a fotovillamos beruházások a kedvező román megtérülési mutatók ellenére nem vonzották annyira a nagytőkét, amely azzal is magyarázható, hogy Románia nem minden régiója alkalmas egyformán naperómúvek hatékony üzemeltetésére (TAPURICA, O.-C.-TACHE, F. 2014).

\section{Magyarország}

Ha megnézzük a természetföldrajzi feltételeket, elmondható, hogy Magyarország kedvező helyzetben van. Az átlagos éves napsütéses órák száma 1800-2100 között szóródik, a déli országrészben (különösen Sellye és Szeged környékén) elérheti a 2500 órát is (Göőz 
L. 2013), s ugyanitt a napsugárzás intenzitása $\left(\mathrm{W} / \mathrm{m}^{2}\right)$, valamint az ebből fakadó összes fajlagos besugárzás $\left(\mathrm{kWh} / \mathrm{m}^{2}\right.$-ben) is nagyobb (1. ábra). A hőmérsékleti viszonyok még tovább kedveznek a napenergia felhasználásának, mivel (a mediterrán és déli országokhoz viszonyítva) az alacsonyabb átlaghőmérséklet miatt a napelemek egységnyi teljesítményre eső áramtermelése nagyobb (FOSTER R. et al. 2010).

„Magyarországon az első kísérleti megújuló energia-termelés jogszabályi keretbe foglalása 1996-ban történt meg. 2000-től van átfogó jogi háttere a megújulóenergia-termelés folyamatának, fó elosztó hálózatokra töltésének és ösztönzésének" (SuvÁK A. 2014, p. 76). Mindezek ellenére hazánkban a fotovillamos piac lassan indult el, és a lassú fejlődés a mai napig jellemző. Fotovillamos erőmúveket elsősorban a telekommunikációs szektorban, valamint vidéki terekben telepítettek, de ez nem vált kereskedelmi értelemben széleskörúvé. Hálózatra kötött telepítések elsősorban a háztartási és a kereskedelmi szektorban történtek, közvetett módon a saját fogyasztás csökkentése érdekében (DusONCHET L.-TelaretTI, E. 2010). A Magyarországon kialakított támogatáspolitikára a fix és kötelező átvételi ár (KÁT) rendszere jellemző, amelynek összege bevezetése óta a környező országokhoz viszonyítva a legalacsonyabb (alig haladja meg a 0,100 EUR/kWh értéket). Ez az ár nagyságrendileg nem változott azóta sem, 2017-ben 0,102 EUR/kWh volt 0,5 MW alatti fotovillamos erőmúvek esetében (vö. 1. melléklet a 165/2016. [VI. 23.] Korm. rendelethez). Emellett Magyarország is biztosít támogatást - jellemzően a strukturális és beruházási alapok különböző operatív programokban megjelenő uniós forrásaiból háztartási és nagyobb léptékű naperőmúvek beruházásaihoz, ám e források hozzáférése esetleges, és az eddigi tapasztalatok alapján többnyire csak rövid ideig áll rendelkezésre.

Magyarországon a jogszabályi háttér nem kedvez az 500 kW-os kapacitásnál nagyobb naperőmúvek telepítésének. Az 500 kW Magyarországon a menetrendadási kötelezettség határát jelenti. A menetrendtől való nagyobb mértékủ eltérés esetén ugyanis a termelő szabályozási pótdíjat köteles fizetni a rendszerirányító számára (Suvák A. 2014). Szlovákiában a menetrendadási kötelezettség $4 \mathrm{GW}$ beépített kapacitás felett lép életbe, amely nyolcszor akkora fejlesztések létrehozását teszi lehetôvé, nem csekély mértékben csökkentve ezzel a fajlagos beruházási költségeket. Így a hazai jogszabályi háttér egy nagyobb $(500 \mathrm{~kW}$ feletti) napelempark optimális üzemeltetését jelentős versenyhátrányba hozza a környező országokhoz képest (NYÁRI Z. 2014).

A pótdíjfizetésre vonatkozó szabályokat a MEKH időszakról időszakra felülvizsgálja és szabályozza. 2018. július 1-jétől szigorodott a menetrendadás. Amellett, hogy a napi helyett negyedórás bontású menetrendadás az előírás, a 0,5 MW alatti erőmúvek is szankcionálhatók (1.http://www.mekh.hu/julius-1-jetol-pontosabb-menetrendtartasi-kovetelmenyek-lepnek-eletbe). A szankció a háztartási kiserómúvekre nem vonatkozik.

További hátrány a hazai befektetők számára, hogy a piaci árhoz képest kedvezőbb átvételi árak messze elmaradnak a környező országok átvételi áraitól, ami a beruházás megtérülési idejét is jelentősen befolyásolja (NYÁRI Z. 2014). Megjegyzendő azonban, hogy a vásárlóerő-paritás számítások alapján ezen országokban Magyarországhoz képest - Romániát leszámítva - az átlagos árszínvonal, míg a villamos energia, gáz és egyéb tüzelőanyagoknál - Romániát és Horvátországot leszámítva - az árszínvonal magasabb volt egészen 2017-ig, amikor Horvátország ez utóbbi árszínvonal tekintetében utolérte Magyarországot (KSH 2012, 2017).

\section{Horvátország}

Horvátországban a megújuló energiák energetikai szabályozása, valamint az intézményrendszer kialakítása nehézkesen indult, sok helyen, sok tekintetben nem voltak a feladat- 
körök (különösen helyi szinten) meghatározva. Az elmúlt években az uniós csatlakozásra való felkészülés, a jogharmonizáció sokat javított a helyzeten (LALIĊ, D. et al. 2011). A termelők által szolgáltatott energiát a horvát egyetemes villamosenergia-szolgáltató, a HROTE veszi át garantált át vételi áron és adja tovább az ellátási hálózat további szereplői felé. Ez a cég van szerződéses kapcsolatban a termelőkkel és az energiaszolgáltatókkal. A megújuló forrásokból származó villamos energia elóállítási ára a villamos energia fogyasztói díjába van beépítve (a végső fogyasztói díj az energiadíj, az ösztönzői díj és az egyéb díjak összege). A beérkezett díjak az elosztási hálózaton visszafelé jutnak el a termelőkig. Az egyetemes szolgáltató gondoskodik arról is, hogy a megújuló forrásokból származó vagy kapcsoltan termelt villamos energia jogszabályban rögzített minimális aránya teljesüljön. A támogatásra jogosult termelók olyan üzemek, amelyek hulladék, vagy megújuló energiaforrások felhasználásával egyazon termelési üzemen belül állítanak elő villamos és hőenergiát, mindezt gazdaságossági és környezetvédelmi szempontok figyelembevételével teszik (SuvÁK A. 2014, p. 75.). A megújuló energián alapuló, illetve a kogenerációs erőműveket érintő ártámogatások mellett egy másik, erős, a megújuló energiaforrások használatát támogató politikai megfontolás jött létre még 2003-ban Horvátországban. Ez a Környezetvédelmi és Energiahatékonysági Alap, amelynek célja, hogy pénzügyi támogatásokat nyújtson környezetvédelmi és a fenntarthatóságot elősegítő projektek finanszírozásához (LALIĊ, D. et al. 2011).

Horvátországban 2007 és 2012 között az átvételi árak kedvezőbbek voltak, mint a jelenlegiek, vásárlóeró-paritás számítások alapján a magyarországinál alacsonyabb árszínvonal mellett (KSH 2012). Ennek hatására jelentős beruházások indultak meg a megújuló energia szektorában. 2012-ben azonban csökkent a megújuló energiából termelt villamos energia kötelező átvételi ára, és még a kapcsolt hőtermelés ellentételezésével sem éri el a korábbi szintet. Ugyanakkor az ügyintézési határidők jelentősen rövidültek 2007 óta, ami viszont egy fontos tényező a termelés tényleges megindításához. A termelói és elosztói engedélyek kiadásának határideje 60 nap (Suvák A. 2014).

\section{Az átalakuló támogatáspolitika}

A megújuló energiaforrások használatának dinamikus térnyerését követően, és annak támogatások nélküli életképességének térnyerése miatt egyre több helyen - így az USAban (CAVICCHI, J. 2017), Japánban (Myojo, S. - OHASHI, H. 2018), Kínában (SHEN, J. - LuO, C. 2015) vagy Európában (NiCOLINI, M. - TAVONI. M. 2017) - fogalmazódik meg a piacot kevésbé torzító, vagy hatékonyabb, de kevesebb forrást igénylő, a megújuló energiára vonatkozó kormányzati támogatáspolitika iránti igény.

Az Európai Unióban - a közös részarány-növelési elhatározás (2009/28/EK) ellenére a megújuló erőforrásból származó villamos energia termelésére vonatkozóan sokáig nem volt egységes támogatáspolitika, ösztönző rendszer. 2014. január 22-én az „Éghajlat- és energiapolitikai keret a 2020-2030-as időszakra" címú közleményében (COM]2014] 15) a Bizottság új energiaügyi és éghajlat-változási célkitűzéseket tett, ehhez kapcsolódóan pedig iránymutatást (2014/C 200/01) adott ki annak érdekében, hogy - többek között a megújuló energiaforrásból származó villamosenergia-termeléshez (beruházáshoz és múködéshez egyaránt) nyújtott (állami) támogatások az unióban egységes elvek mentén valósuljanak meg. Az iránymutatás így a nagy (500 MW beépített kapacitás feletti) termelőket a piacra tereli, továbbá a támogatást a piaci áron felüli felárként kell nyújtani. 2017-től (az 1 MW feletti termelőknél) a támogatást versenyeztetéses ajánlattételi eljárás során kell nyújtani. Bár a bevezetett támogatási eljárások fajlagosan kisebb állami forrás- 
allokációt igényelnek - például a betáplálási tarifa rendszerénél -, ugyanakkor NiCOLINI, M.-TAVONI, M. (2017) rámutatnak arra, hogy a betáplálási tarifának (illetve az emelkedésének) mérhető hatása van a megújuló beruházások növekedésére, s ez a hatás nagyobb például a zöldbizonyítvány rendszereknél. A betáplálási tarifa hatékonyságát korábban már Dong, C. G. (2012) is alátámasztotta.

Ahogy a 2. ábrán látható, a vizsgált Kárpát-medencei országok összes beépített fotovillamos kapacitása egy hirtelen növekedést követően stagnál, azaz, a beruházásokat viszszafogták, amely részben a támogatáspolitika (uniós szabályozási szintű) átalakulásával magyarázható. A kezdeti erőteljesebb támogatást követte a támogatások visszanyesése, amely több - elsősorban kelet-közép-európai országban - visszamenőleges hatályú volt. Ennek egyik riasztó példája Csehország. Bár nem tekinthető Kárpát-medencei országnak, mégis érdemes az esetet vizsgálni, hogy felhívjuk a figyelmet egy félresikerült támogatáspolitikára, illetve annak tovagyúrúző hatásaira. Csehországban a megújuló energiával - elsősorban a fotovillamos energia termelésével - kapcsolatos politika ugyanis azt eredményezte, hogy 2010-ben a beépített kapacitások nagysága extrém módon megnőtt (megközelítve az akkori spanyol értékeket). A megújuló energia terén Csehország 2010-es célaránya a villamosenergia-felhasználásban $8 \%$ volt, amelytől 2008-ig igen messze volt, és az évenkénti megújuló energetikai riportokban a 2010-es részarány elérését irreálisnak ítélték. A lemaradás okai a szükséges uniós szabályozások átültetésének késése, valamint a megújuló villamosenergia-termelés támogatásáról szóló jogalkotási késedelem voltak. Így a 2010-es 8,24\%-os publikált arány meglepetés volt. Ennek több oka volt. Egyrészt a 2010-es extrém csapadékos időjárásnak köszönhetően a vízerőmúvek termelése magasabb volt (129\%-a az átlagosnak), másrészt a beépített fotovillamos kapacitás megnövekedett 2009-ben, különösen pedig 2010-ben, harmadrészt a 2009-es értékekhez képest a biogázból termelt villamos energia aránya is megnőtt 2010-re az előző évihez képest. Mindemellett összességében a villamos energia (hagyományos) termelése és a fogyasztás is csökkent a gazdasági válság hatására (SIVEK, M. et al. 2012). A fotovillamos energia termelésének extrém növekedése az erős politikai és gazdasági támogatottságnak volt köszönhető, ugyanis az elosztó kötelező átvenni a megújuló forrásból származó villamos energiát fix áron, amit 15+5 évre garantálnak (SIVEK, M. et al. 2012). A még 2005-ben elfogadott, a cseh Kereskedelmi és Ipari Minisztérium által jegyzett jogszabály alapján a 2006. január 1-ét követóen üzembe helyezett megújuló energiaforrásból villamos energiát termelő cégek minden évben (újragondolva!) választhatnak a fix tarifa, valamint a prémiumár között. A fix árat 20 évre garantálja a cseh állam. Az Energia-szabályozási Iroda minden évben újraszámolja az árakat a piaci viszonyok függvényében, azonban a jogszabály alapján a fix ár csökkenése nem haladhatja meg az évenkénti 5\%-ot. A fotovillamos rendszerekre vonatkozó fix tarifa és zöld prémiumár rendszere 2009. január 1-jétől lépett hatályba. A fentiek mellett a fotovillamos rendszerek telepítését adókedvezménnyel, beruházásösztönzéssel és kedvező hitelkamatokkal kezdték el támogatni ebben az időben (Dusonchet, L. - TelareTti, E. 2010). Az aktív támogatáspolitikának köszönhetôen a 2008-as 39,5 MW beépített fotovillamos kapacitás 2009-re 464,6 MW-ra, míg 2010-re 1959,1 MW-ra emelkedett (Energy Regulatory Office, 2009-2011). 2013 év végén ez az érték 2132 MW volt, amely az összes villamosenergia-termelő kapacitás 10,1\%-a (ERÚ 2014). A beépített kapacitások hirtelen növekedése 2010 februárjában megállt, mivel a cseh állami áramelosztó és rendszerirányító vállalat technikai és pénzügyi fékekkel felfüggesztette a fotovillamos erőmúvek csatlakozási engedélyeinek kiadását (SIVEK, M. et al. 2012). A nagyon magas, hosszú időre garantált átvételi ár miatti beruházási, befektetői boom, valamint a fogyasztói villamos energia árának hirtelen emelkedése - az áram fogyasztói ára a 2010-es 6,7 EUR/MWh-ról 2012-re 16,8 EUR/MWh-ra növekedett (ERÚ, 2011) - 
következtében a cseh szenátus 2010 végén kénytelen volt visszamenőlegesen módosítani a megújuló energiákra vonatkozó politikáját, amely szerint a 2009-2010 között telepített 30 kW feletti kapacitású erőmúvekre 26\%-os nyereségadót vetett ki, ezzel próbálva megállítani a növekvő fogyasztói árakat. Bár a tiltakozás nagy volt, az ártámogatási rendszer megmaradt a már korábban kiadott engedményezések mellett, a 26\%-os nyereségadó kivetése és megtartása ugyanakkor megrendítette a befektetői bizalmat (SIVEK, M. et al. 2012, PRŮŠA, J. et al. 2013). A támogatások visszafogása érezteti hatását, hiszen a telepítések nagyságrendje kisebb lett (2.ábra), 2013-ban „,csak” 88 MW-nyi fotovillamos kapacitásfejlesztés történt (http://www.photon.info/photon_news_detail_en.photon?id=84610)

A vizsgált Kárpát-medencei országokban hasonló hirtelen kapacitásbővítés és az arra adott (szak)politikai válasz nem fordult elő, ugyanakkor Romániában egy nagyon erős növekedést követő lecsengésnek lehetünk tanúi, ahogyan Szlovákiában is. Szlovákiában a beépített kapacitás visszaesésére is felfigyelhetünk, amelynek okairól az URSO (a szlovák rendszerszabályozó) nem ad tájékoztatást riportjaiban. Erre vélhetőleg egy-egy engedély visszavonása, esetleg a nem egységes számítási mód adhat magyarázatot (vö. https://www.photon.info/en/news/slovakia-registered-negative-growth-installed-pv-capacity-2013). Ugyanakkor a hirtelen növekedés kormányzati büdzsére gyakorolt negatív hatásai miatt Szlovákia 2013-ban a már meglévő és múködő fotovillamos erőmúvekre bevezetett egy ún. G komponenst, amely lényegében egy extra adó. Ezt végül a szlovák bíróság alkotmányellenesnek minősítette 2016-ban, így a befizetett adót a kormánynak visszamenőlegesen is vissza kell fizetni az energiatermelőknek.

Románia robbanásszerű fejlődése elsősorban a megnövekedett tőkevonzó képesség, valamint a fotovillamos panelek árának drasztikus csökkenése miatt indult meg, ami a relatíve alacsony fiskális támogatási igényû zöldbizonyítvány-rendszer költségvetési hatását drasztikusan megemelte. 2013-ban ezért a román kormány megfelezte a kiadható zöldbizonyítványok mennyiségét (ahogy fentebb említésre került), illetve a 3 zöldbizonyítványból 2 kereskedését engedélyezte 2017-ig; a visszatartott 3. bizonyítványokat 2018-tól is csak fokozatosan lehet a piacra vinni (NĂSTASE, G. et al. 2018).

Magyarország és Horvátország fotovillamos energiát termelő beépített kapacitása sokáig hasonlóan alacsony szintú volt. A megújuló forrásokból vagy kapcsoltan termelt energia támogatásában mindkét országban a kötelező átvételi árak játsszák a legfontosabb szerepet. Ennek mértéke, a támogatás garantált időszaka és a kapcsoltan termelt többlet hőenergia ellentételezése együttesen határozza meg az átvételi árak rendszerét. 2010 után mindkét országban visszaesett a megújuló energiából előállított villamos energia támogatása. Horvátországban az átvételi árak csökkentek, Magyarországon pedig a kapcsolt hőenergia termelésének ellentételezése szűnt meg. Ezen túl Magyarországon a villamosenergia-törvény módosítása miatt 2011 júliusától a kötelezően átveendő KÁT villamos energia mennyisége is lényegesen csökkent. A megújuló energiákból elő́llított villamos energia kötelezó átvételi ára Horvátországban folyamatosan magasabb szinten volt, mint Magyarországon, alacsonyabb villamos energetikai árszínvonal mellett (KSH 2012). A naperőmúvek esetében ez 2012 előtt négyszeres különbséget jelentett. A jelentős árcsökkenés (2007-től 3,40, 2012-től 2,63, majd 2013-tól 1,91 kuna/kWh, kb. 0,144 EUR/kWh) után a horvát bázisárak még mindig magasabbak maradtak, mint Magyarországon (0,109 EUR/ kWh; SuvÁK A. 2014). Megemlítendő továbbá, hogy a megújuló energiák termelésében Horvátországban a hálózaton kívüli megoldásoknak nagy a szerepe. Magyarországon a központi hálózatra feltöltés a központilag támogatott eljárás (SUvÁK A. 2014).

Bár a horvátországi kezdeti támogatáspolitika a magyarországinál jobban segítette a beruházások elindulását, a folyamatosan csökkenő, majd végül 2016-ban (felmenő rendszerben) megszúnő hagyományos betáplálási tarifa nem emelte meg a befektetési ked- 
vet, annak ellenére, hogy Horvátország déli, délkeleti területeinek elméleti potenciálja kiemelkedő. (Megjegyzendő ugyanakkor, hogy a betáplálási tarifa, illetve a beruházások a szélenergia szektorba irányultak a gyorsabb megtérülés miatt.) A szabályozás abba az irányba próbálja meg eltolni a fotovillamos energiába befektetőket, hogy első körben saját fogyasztásra termeljenek, majd a maradékot értékesítsék (a HROTE átveszi, de sokkal alacsonyabb áron, mint a korábbi betáplálási tarifa ára volt). A fotovillamos energiát termelő szektorra a csökkenő intenzitású támogatáspolitikának több hatása is volt: 2017-ben mindössze 4 naperőmúvet adtak át Horvátországban; a kiserőmúvi beruházások eltolódtak a közszektor irányába, ahol a nappal termelt energiát nappal fel is tudják használni; a korábbi 6-8 éves beruházás-megtérülések 18-20 évre nőttek (FEKETE, K. 2018).

Magyarországon a fotovillamos energiát illetően a beruházások szintje sokáig alacsony volt. A napelemekre kivetett környezetvédelmi termékdíj, a környező országoknál szigorúbb szabályozások a naperőmú-beruházások mennyiségének lassú fejlődését eredményezték (figyelembe véve a beruházási támogatásokat is). Bár 2016-ban például 26 új naperőmú került be a KÁT rendszerébe (http://www.mekh.hu/jelentosen-nott-a-naperomuvi-termeles), a 2017-es KÁT/METÁR rendszer az új beruházások ütemét vélhetően visszaveszi. A 2.ábrára tekintve azonban az figyelhető meg, hogy a magyar beruházások fotovillamos energia termelésére stabil növekedést mutatnak. A MEKH adatainak elemzése alapján ennek oka elsősorban a háztartási méretű kiserőmúvek (HMKE) erőteljes növekedése. (Az $50 \mathrm{~kW}$ feletti mérettartományban is növekszik a nem engedélyköteles kiserőmúvek száma, de a trendnövekedés egyértelműen az 50 kW alatti HMKE-knek köszönhető.) A hazai összes beépített 208 MW kapacitásból 164 MW tartozott az 50 kW alatti kategóriába. A 164 MW kapacitásból 32 MW jutott a kifejezetten kis (4 fős) háztartási (5kW alatti) „erőmúvekre”, 37 MW a nagyobb háztartási (5-10kW) kategóriára, míg közel 95 MW a 10-50kW közötti erőmúvekre; ez utóbbi tipikusan közintézmények vagy vállalatok villamos energiával való ellátására alkalmas méretkategória. A magyar szabályozás a maga relatív alacsony átvételi árával (amely a kiserőmúvekre a METÁR bevezetése után is megmarad), illetve a kormány árnövelő szándéka (környezetvédelmi termékdíj a napelemekre) ellenére a napelemek, valamint az inverterek árának drasztikus csökkenése a tôkeerősebb háztartásokat és a kisvállalatokat, továbbá - részben, pályázati forrásokon keresztül a közintézményeket a kisméretû, a saját fogyasztást többé-kevésbé fedezó fotovillamos energia termelése irányába tolta el. Az uniós szabályozásnak köszönhetően a 2017. január 1-jétől induló METÁR rendszer, az annak részeként múködő METÁR KÁT és prémium támogatási rendszer, illetve a legkisebb méreteknél megmaradó KÁT kevesebb fiskális támogatással kecsegtet, így a fotovillamos (és általában a hazai megújuló) energiatermelő kapacitások eddiginél lassabb növekedésével lehet számolni.

\section{Összefoglalás}

A vizsgált Kárpát-medencei országok elméleti napenergia-potenciálja (a besugárzás különbségéból fakadóan) dél felé növekszik, a beruházások időbeli alakulása azonban teljesen más képet mutat. Romániában és Szlovákiában egy erős hirtelen növekedést követő stagnálás, Horvátországban egy óvatos emelkedés, majd stagnálás, míg Magyarországon egy folyamatos, de viszonylag lassú emelkedés figyelhető meg. Ennek okai egyértelmúen nem a földrajzi adottságokban keresendők, hanem a különböző nemzeti támogatáspolitikákban, amelyet 2017-től egy „központi”, uniós támogatási iránymutatás mozgat. Bár

jelenleg nem látható, hogy ennek milyen következményei lesznek, ugyanakkor a már bejárt utak miatt feltételezhető, hogy Magyarország fotovillamos energetikai fejlődését 
az új uniós szabályozás nem fogja visszavetni, hiszen a magyar fejlődés markáns része abba a (kiserőmúvi) kategóriába esik, amelyet nem érint az uniós támogatás. Ugyanakkor a másik három országban - a korábbi hosszú távú kormányzati elköteleződések miatt a beruházások stagnálása várható.

Áttekintve a támogatáspolitika változásait - részben az EU iránymutatása alapján mindenhol az látható, hogy a betáplálási tarifa, mint ösztönző rendszer háttérbe szorul, elsősorban a nagyobb kapacitású erőmúveknél, s helyét a kormányzati költségvetést kisebb mértékben megterhelő ösztönzők veszik át. Ennek az átalakulásnak akkor van pozitív hatása, ha egy adott területi egység már elérte kitűzött megújuló energetikai célját, s a továbbiakban az ösztönzőrendszer (és a megújuló energiaforrások támogatásának) megtartása mellett kisebb ráfordításokat szeretne eszközölni. Ezt a fajta 'hatékonyságáthelyeződést' elemzik ZHANG, G. et al. (2017), akik három fontos megállapításra jutnak: 1) a megújuló energetikai bizonyítványok kereskedelmének rendszere (ilyen van Romániában is) csökkenti a kormányzat megújuló energiákat támogató kiadásait; 2) a zöldbizonyítvány és a zöldbizonyítvány kvótarendszer (korábban említett RPS) - szemben a betáplálási tarifával - csökkenti a (megújuló) energetikai szektor profitját, azaz a betáplálási tarifa növeli a profitot (nem véletlenül volt számos tárgyalt országban hirtelen növekedés, amelyet a kormányok visszamenőleges szabályozással próbáltak „orvosolni”); és 3) ugyanakkor a zöldbizonyítvány és az RPS együttesen nem elég hatékony egy térség megújuló energetikai céljainak elérésében (különösen magas tőkebefektetést igénylő ágazat esetében). Így a szerzők vizsgálata szerint a három eszköz együttes, kiegyensúlyozott, időben eltolódó alkalmazása célszerú.

\title{
Köszönetnyilvánítás
}

Jelen tanulmány IPA REGPHOSYS (HUHR/1101/2.1.3/0002), valamint az INTERREG V/A (HUHR/1601/3.1.1/0033) projektek kutatási eredményeire is épít. A tanulmány a Változás és folytonosság a magyar térképzetekben: nemzet, területiség, fejlesztés és határpolitika címú NN 114468 témaszámú Nemzeti Kutatási, Fejlesztési és Innovációs Hivatal (NKFIH) kutatás keretében készült. A tanulmány megírását és a kutatást a Bolyai János Kutatási Ösztöndíj támogatta.

\author{
VARJÚ VIKTOR \\ MTA KRTK Regionális Kutatások Intézete, Pécs \\ varju@rkk.hu
}

\section{IRODALOM}

AydoĞAn, B. 2017: Offshore windpower atlas of the Black Sea Region. - Journal of Renewable and Sustainable Energy 9. https://doi.org/10.1063/1.4976968. Letöltés: 2018.07.01.

BENEDEK J.-SEBESTYÉN T. T.-BARTóK B. 2018: Evaluation of renewable energy sources in peripheral areas and renewable energy-based rural development. - Renewable and Sustainable Energy Review 90. pp. 516-535.

BoRENSTEIN, S. 2012: The private and public economics of renewable electricity generation. - Journal of Economic Perspectives 26. 1. pp. 67-92.

Cămpeanu, V.-Pencea, S. 2014: Renewable energy sources in Romania: from a ,paradise” of investors to a possible abandon or to another boom? The imapct of a new paradigm in Romanian renewable sources policy. - Procedia Economics and Finance 8. pp. 129-137.

CAVICCHI, J. 2017: Rethinking government subsidies for renewable electricity generation resources. - The Electricity Journal 30. 6. pp. 1-7. 
Cheung, G.-DAvies, P. J.-TRÜCK, S. 2016: Financing alternative energy projects: An examination of challenges and opportunities for local government. - Energy Policy 97. pp. 354-364.

Couture, T.-CoRY, K. 2009: State clean energy policies analysis (SCEPA) project: an analysis of renewable energy feed-in tariffs in the United States. - National Renewable Energy Laboratory, Technical Report NREL/TP-6A2-45551, Colorado. $51 \mathrm{p}$.

Couture, T.-GAGnON, Y. 2010: An analysis of feed-in tariff remuneration models: Implications for renewable energy investment. - Energy Policy 37. 12. pp. 4997-5006.

Csikósová, A.-Antosová, M.-Senová, A.-Culková, K. 2012: Economical analysis of the photovoltaic systems - Case study Slovakia. - AASRI Procedia 2. pp. 186-191.

Csomós Gy. 2014: Az olajipari transznacionális vállalatok kapcsolata a megújulóenergia-szektorral: Alkalmazkodás a 21. század globális elvárásaihoz vagy csak szemfényvesztés? - Földrajzi Közlemények 138. 3. pp. $165-180$.

Dong, C. G. 2012: Feed-in tariff vs. renewable portfolio standard: An empirical test of their relative effectiveness in promoting wind capacity development. - Energy Policy 42. pp. 476-485.

Dusonchet, L.-TelaretTi, E. 2010: Economic analysis of different supporting policies for the production of electrical energy by solar photovoltaics in eastern European Union countries. - Energy Policy 38. pp. 4011-4020.

ECOFYS 2005: Global potential of renewable energy sources: a literature assessment by order of REN21. - Renewable Energy Policy Network for the $21^{\text {st }}$ Century. 45 p.

ERÚ 2011: Price decree 5/2011. Energeticky Regulacní Úrad.

ERÚ 2014: Yearly report in the pperation of the Czech Electricity Grid for 2013. Prague. http://www.eru.cz/documents/10540/462820/Annual_report_electricity_2013.pdf/34a35d27-9c58-4c7999d1-f0fbc5eac06a. Letöltés: 2018.07.01.

FARKAS I. 2005: Termikus napenergia potenciál a magyar mezőgazdaságban. - Energiagazdálkodás 46. 1.pp.3-7.

FARKAS I. 2010: A napenergia hasznosításának hazai lehetőségei. - Magyar Tudomány 171. 8. pp. 937-946.

FARKAS I. 2017: Napenergia-hasznosítás - Hazai és nemzetközi helyzetkép. - Magyar Tudomány 178. 5. pp. 517-523.

FEKETE, K. 2018: Levelized cost of PV systems in cross border region. rures.eu/filebrowser/download/20241. Letöltés: 2018.07.02.

Foster R.-GHASSEMI, M.-CotA, A. 2010: Solar energy. Renewable energy and the environment. - CRC Press, Boca Raton. 380 p.

Göőz L. 2013: The feasibility of micro-regional autonomous energy systems. - In: BoKOR L.-CSAPÓ J.-SzELESI T.-Wilhelm Z. (szerk.): Locality and the energy resources. Frugeo, Shrewsbury. pp. 118-131.

HoReCZKi R. 2014: Fotovoltaikus rendszerek fejlődése a környező országokban - Románia és Szlovákia. - In: VARJÚ V. (szerk.): Napelemes energia és környezet. MTA KRTK RKI-ETFOS, Pécs-Osijek. pp. 107-113.

HVG 2011: Zöldenergia: ahány ország annyiféle ösztönzés. http://hvg.hu/gazdasag/20110421_z9oldenergia_tamogatas_eu. Letöltés: 2018.07.01.

JäGER-WALDAU, A. 2017: PV Status Report 2017, JRC Science for Policy Report. http://publications.jrc.ec.europa.eu/repository/bitstream/JRC108105/kjna28817enn.pdf. Letöltés: 2018.07.01.

JENNER, S.-GROBA, F.-INDVIK, J. 2013: Assessing the strength and effectiveness of renewable electricity feedin tariffs in European Union countries. - Energy Policy 52. pp. 385-401.

KASSAI-Szoó D. 2014: Városi tetőfelületeken hasznosítható szoláris potenciál.- In: SzABó V.-FAZEKAS I. (szerk.): Környezettudatos energiatermelés és -felhasználás. III. Környezet és Energia Konferencia. MTA DAB Megújuló Energetikai Munkabizottság, Debrecen. pp. 128-134.

KATSAPRAKAKIS, D. A.-ChristAKIS, D. G. 2016: The exploitation of electricity production projects from renewable energy sources for the social and economic development of remote communities. The case of Greece: an example to avoid. - Renewable and Sustainable Energy Review 54. pp. 341-349.

KSH 2012: Az árszínvonal összehasonlítása az európai országok között (a 2011-re vonatkozó vásárlóerőparitás-számítások alapján). https://www.ksh.hu/docs/hun/xftp/idoszaki/pdf/arszinvonaleuropa11.pdf

KSH 2017: STADAT, Relatív árszínvonal. http://www.ksh.hu/docs/hun/xstadat/xstadat_eves/i_int048a.html

Lalić, D.-Popovski, K.-GeČevska, V.-Popovska Vasileska, S.-Tesić, Z. 2011: Analysis of the opportunities and challenges for renewable energy market in the Western Balkan countries. - Renewable and Sustainable Energy Reviews 15. pp. 3187-3195.

MendonçA, M.-JACOBS, D. 2009: Feed-in tariffs go global: policy in practice. - Renewable Energy World Magazine 12. 4. https://www.renewableenergyworld.com/articles/print/volume-12/issue-4/solar-energy/ feed-in-tariffs-go-global-policy-in-practice.html. Letöltés: 2018.07.01.

Mezei C. 2014: Támogatás politika. - In: VARJú V. (szerk.): Napelemes energia és környezet. MTA KRTK RKI-ETFOS, Pécs-Osijek. pp. 38-39.

MunKáCsy B. 2010: A területi tervezés szorításában - A szélenergia-hasznosítás hazai lehetőségei. - Területfejlesztés és Innováció 4. 2. pp. 20-27. 
Myojo, S.-OHASHI, H. 2018: Effects of consumer subsidies for renewable energy on industry growth and social welfare: The case of solar photovoltaic systems in Japan. - Journal of the Japanese and International Economies 48. pp. 55-67.

NAGY S. Gy.-LÓRÁND B. 2013: Evaluation of EU Fund dependency - Dead weight loss and substitution effect. - In: PÁlné Kovács I.-Scott, J.-GÁl Z. (szerk.): Territorial cohesion in Europe. IRS CERS HAS, Pécs. pp. 109-119.

Năstase, G.-Șerban, A.-Dragomir, G.-Brezeanu, A. I.-Bucur, I. 2018: Photovoltaic development in Romania. Reviewing what has been done. - Renewable and Sustainable Energy Review 94. pp. 523-535.

NÉMETH K. 2017: Vidéki térségek innovációs kihívásai. Megújuló energia alternatívák. - Pannon Egyetemi Kiadó, Veszprém. 122 p.

NÉMETH K.-PÉTER E. 2017: System-oriented approaches to the utilization of renewable energy sources. - In: BuKOR J.-KorCSMÁROs E. (szerk.): A Selye János Egyetem 2017-es „Érték, minőség és versenyképesség - a 21. század kihívásai” Nemzetközi Tudományos Konferenciájának tanulmánykötete: Zborník medzinárodnej vedeckej konferencie Univerzity J. Selyeho, Selye János Egyetem, Komarno. pp. 334-346.

Nicolini, M.-TAvoni, M. 2017: Are renewable energy subsidies effective? Evidence from Europe. Renewable and Sustainable Energy Reviews 74. pp. 412-423.

NYÁRI Z. 2014: A Sellyei Naperómú. - In: VARJÚ V. (szerk.): Napelemes energia és környezet. MTA KRTK RKI-ETFOS, Pécs-Osijek. pp. 105-107.

PÁlfy M. 2017: A napenergia fotovillamos hasznosítása - Trendek, hazai alkalmazások. - Elektrotechnika 110. 10. pp. 24-27.

Pelin, D.-Šljivac, D.-Topić, D.-VARJú V. 2014: Regional impacts of different photovoltaic systems. - ID Research Kft. - Publikon Kiadó, Pécs. 304 p.

PRŮŠA, J.-KlimeŠovÁ, A.-JANDA, K. 2013: Consumer loss in Czech photovoltaic power plants in 2010-2011. - Energy Policy 63. pp. 747-755.

RUDLNÉ BANK K. 2008: A megújuló energiaforrások szerepének átértékelődése Európában és Magyarországon - különös tekintettel a technikai innovációra és a gazdasági lehetőségekre. - Földrajzi Közlemények 132. 1. pp. 35-51.

Sarasa-Maestro, C. J.-Dufo-López, R.-Bernal-Agustín, J. L. 2013: Photovoltaic remuneration policies in the European Union. - Energy Policy 55. pp. 317-328.

SHEN, J.-LuO, C. 2015: Overall review of renewable energy subsidy policies in China - Contradictions of intentions and effects. - Renewable and Sustainable Energy Review 41. pp. 1478-1488.

SíveK, M.-Kavina, P.-MALEČKova, V.-JiRÁSEK, J. 2012: Czech Republic and indicative targets of the European Union for electricity generation from renewable sources. - Energy Policy 44.pp. 469-475.

ŠluIVAC, D. 2015: Solar Energy Resources int he Danube Region. - In: ORTIZ, W.-SOMOGYVÁRI M.-VARJú V.-Fodor I.-LECHTEnbÖHMER, S. (szerk.): Perspectives of renewable energy in the Danube Region. IRS CERS of HAS, Pécs. pp. 257-266.

SuvÁK A. 2014: A fotovoltaikus energiatermelés jogszabályi és intézményi háttere Magyarországon és Horvátországban. - In: VARJú V. (szerk.): Napelemes energia és környezet. MTA KRTK RKI-ETFOS, PécsOsijek. pp. $73-83$.

TAPURICA, O.-C.-TACHE, F. 2014: An empirical analysis of the projects aiming sustainable energy development (SED) in Romania. - Renewable and Sustainable Energy Reviews 37. pp. 13-20.

Timilsina, G. R.-Kurdgelashvili, L.-Narbel, P. A. 2012: Solar energy: Markets, economics and policies. - Renewable and Sustainable Energy Reviews 16. pp. 449-465.

Tóтн A. N. 2016: Magyarország geotermikus felmérése.-Magyar Energetikai és Közmú-szabályozási Hivatal, Budapest. $182 \mathrm{p}$.

VÉGH L. 2015: Decreasing negative ecological impacts of PV farms: identification of suitable areas in Hungary. - In: Ortiz, W.-Somogyvári, M.-VARJú V.-Fodor I.-LechtenbÖHMER, S. (szerk.): Perspectives of renewable energy in the Danube Region. IRS CERS of HAS, Pécs. pp. 267-277.

Zhang, Q.-WANG, G.-Li, Y.-Li,H.-MCLellan, B.-ChEN, S. 2017: Substitution effects of renewable portfolio standards and renewable energy certificate trading for feed-in tariff. - Applied Energy 227. pp. 426-435. 